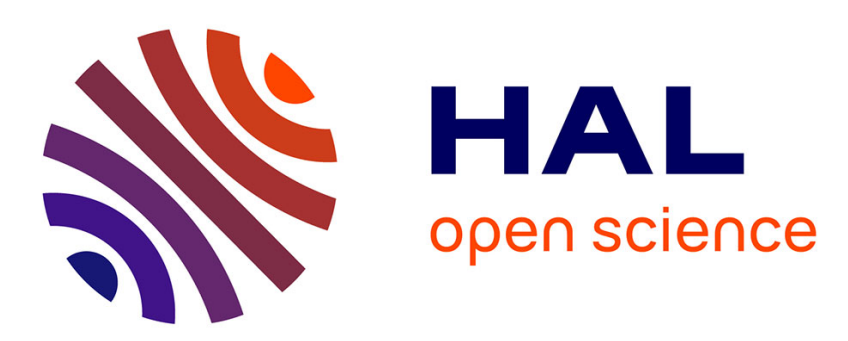

\title{
Trophic transfer of radioisotopes in Mediterranean sponges through bacteria consumption
}

Thomas Lacoue-Labarthe, Michel Warnau, Laureen Beaugeard, Pierre-Yves

Pascal

\section{- To cite this version:}

Thomas Lacoue-Labarthe, Michel Warnau, Laureen Beaugeard, Pierre-Yves Pascal. Trophic transfer of radioisotopes in Mediterranean sponges through bacteria consumption. Chemosphere, 2016, 144, pp.1885-1892. 10.1016/j.chemosphere.2015.10.046 . hal-01217273

\section{HAL Id: hal-01217273 \\ https://hal.science/hal-01217273}

Submitted on 19 Oct 2015

HAL is a multi-disciplinary open access archive for the deposit and dissemination of scientific research documents, whether they are published or not. The documents may come from teaching and research institutions in France or abroad, or from public or private research centers.
L'archive ouverte pluridisciplinaire HAL, est destinée au dépôt et à la diffusion de documents scientifiques de niveau recherche, publiés ou non, émanant des établissements d'enseignement et de recherche français ou étrangers, des laboratoires publics ou privés. 


\section{Trophic transfer of radioisotopes in Mediterranean sponges through bacteria consumption}

Thomas Lacoue-Labarthe ${ }^{1,2, \dagger}$, Michel Warnau ${ }^{1}$, Laureen Beaugeard ${ }^{2}$, Pierre-Yves Pascal $^{3}$

${ }^{1}$ International Atomic Energy Agency - Environment Laboratories, 4 Quai Antoine ${ }^{\mathrm{er}}$, MC 98000 Monaco, Monaco

${ }^{2}$ Littoral Environnement et Sociétés, UMR 7266 CNRS - Université de La Rochelle, 2 rue Olympe de Gouges, 17000 La Rochelle, France.

${ }^{3}$ Département de Biologie, Université des Antilles et de la Guyane, UMR 7138 UPMCCNRS-MNHN-IRD, Equipe 'biologie de la mangrove', UFR des Sciences Exactes et Naturelles, BP 592, 97159 Pointe-à-Pitre, Guadeloupe, France

$\dagger$ Corresponding author: UMR 7266 CNRS-Université de La Rochelle, Institut du Littoral et Environnement, 2 rue Olympe de Gouges, 17000 La Rochelle, France, +33 54645 83 88, tlacouel@univ-lr.fr 


\section{Keywords}

\section{Sponges}

Trophic route

Metal bioaccumulation

Bacteria

Radiotracers

Biomonitor 


\begin{abstract}
Numerous field studies highlighted the capacities of marine sponges to bioaccumulate trace elements and assessed their potential as biomonitors of the marine environment. Experimental works demonstrated that dissolved metals and radionuclides can be taken up directly by sponge tissues but, to the best of our knowledge, little is known on the contribution of the dietary pathway through the consumption of contaminated bacteria considered as one of the trophic source in sponge diet. Objectives of this work are to study trophic transfer of radiotracers ${ }^{110 \mathrm{~m}} \mathrm{Ag},{ }^{241} \mathrm{Am},{ }^{109} \mathrm{Cd},{ }^{57} \mathrm{Co},{ }^{134} \mathrm{Cs},{ }^{54} \mathrm{Mn}$ and ${ }^{65} \mathrm{Zn}$ from the marine bacteria Pseudomonas stutzeri to the Mediterranean sponges Aplysina cavernicola and Ircinia oros. $P$. stutzeri efficiently bioaccumulated trace elements in our culture experimental conditions with CF comprised between $10^{5}$ and $10^{7}$ after 48 hours of growth in radiolabeled medium. When fed with these radiolabelled bacteria, A. cavernicola took up around $60 \%$ of radiotracers accumulated in trophic source except ${ }^{134} \mathrm{Cs}$ for which only $8 \%$ has been transferred from bacteria to sponge. Contrasting to this, I. oros retained only $7 \%$ of ${ }^{110 \mathrm{~m}} \mathrm{Ag},{ }^{109} \mathrm{Cd}$ and ${ }^{65} \mathrm{Zn}$ counted in bacteria, but retained 2-fold longer accumulated metals in its tissues. The sponge inter-specific differences of accumulation and depuration following a trophic exposure are discussed with respect to the structure and the clearance capacities of each species.
\end{abstract}




\section{Introduction}

Over the last 50 years, industrial and urban discharges considerably increased the input of foreign chemicals such as metals in coastal environment (Zhou et al., 2008). Heavy metals form complexes with organic compounds and lead to malfunction or death of affected cells. Consideration of this toxicity is essential in the management of coastal areas and the evaluation of heavy metal concentrations in marine environment is consequently a widespread concern. Measuring dissolved heavy metal presents analytical problems due to detection limits and contamination biases (Rainbow, 1995a). Water contamination is difficult to infer from sediment as benthic accumulation is strongly linked with sediment characteristics such as grain size and organic content (Luoma, 1990). Analysis of heavy metal accumulated by marine organisms overcomes these disadvantages as tissues could be highly concentrated at rates proportional to environmental concentrations. Furthermore, only the bioavailable fraction of metal presenting ecotoxicological relevance is measured and reflects metal availability over longtime period. For those different reasons, biota concentrations are routinely used to monitor environmental contamination and there is a continuous need for new marine biomonitors (Phillips and Rainbow, 1993; Conti and Iacobucci, 2008). Ideal biomonitor should be sedentary, abundant, easy to identify, widely dispersed, long lived and should accumulate heavy metal in his tissue at rate proportional to environmental contamination (Rainbow, 1995b). Mussels have been the group most commonly used in heavy metal biomonitoring however sponge have been proposed as an additional group since they can dominate benthic community and are adapted to various ecological niches extending world widely from intertidal zones to deep sea (Patel et al., 1985; Pérez et al., 2005a; Cebrian et al., 2007a). By their filtering activity, sponges present high capacity to collect and concentrate heavy metals from dissolved and suspended phases (Hansen et al., 1995). Integration of heavy metal in sponge varies according to species (Patel et al., 1985) due to different amount of skeleton fibers and mesohyl in their tissues (Verdenal et al., 1990). Short and long life cycle sponge integrate contamination at different time scale and can be used simultaneously for a more effective monitoring of heavy metal pollution (Batista et al., 2014). As a result, knowledge about accumulation strategies of particular metals is clearly a prerequisite to use sponge as biomonitor.

Dissolved fraction of metal can be taken up directly by sponge tissues but also indirectly by their symbiotic bacteria that contribute to their nutrition and health and can represent $40 \%$ of sponge volume (Hentschel et al., 2006). Sponge species densely packed 
with symbiotic bacteria are known to extract considerable amount of Dissolved Organic Mater (DOM) from the water (Reiswig, 1981; Yahel et al., 2003; De Goeij et al., 2008) and this flux can be significant enough to structure marine environment at ecosystem scale (de Goeij et al., 2013). Assimilation of heavy metal associated with DOM (Iyer et al., 2005) could consequently be an important way of contamination for sponges (Webster et al., 2001). Sponge can also take up metals from the suspended particles collected during feeding. This filter feeding activity is based on pumping ambient water through an intricate system of aquiferous canals to choanocyte chambers where suspended particules are retained by sieving and then phagocyted (Ulrick Riisgård and Larsen, 2010). Sponges can retains diatom, flagellate and ciliate (Coma et al., 2001) however this filtering system is rather specialized in retaining smaller preys (size range 0.1 to $2 \mu \mathrm{m}$ ) such as cyanobacteria, bacteria (Ribes et al., 1999b; Trussell et al., 2006; Yahel et al., 2007) and viruses (Hadas and Marie, 2006). The fact that sponges are able to retain smaller particles than most filter feeders is an adaptative advantage, particularly in oligotrophic environment (Ribes et al., 1999a). Bacteria have been considered as one of the primary source of energy in sponge diet (Pile et al., 1996; Kowalke, 2000).

Bacteria can take up heavy metals at rates high enough to be considered for remediation in polluted environments (Valls and Lorenzo, 2002; Malik, 2004). The cell surface of bacteria carries a net negative charge and can passively adsorb appreciable quantities of positively charged cationic metals (Brierley, 1990; Scott and Palmer, 1990). Metal can also actively pass across the cell membrane through the cell metabolic cycle and bind to intracellular compounds (Malik, 2004). Both modes of metal uptake give to bacteria good bioaccumulation properties.

The aim of the present study is to enrich bacteria Pseudomonas stutzeri with different metals and radionuclides ( $\left.\mathrm{Mn}, \mathrm{Co}, \mathrm{Zn}, \mathrm{Ag}, \mathrm{Cd},{ }^{137} \mathrm{Cs},{ }^{241} \mathrm{Am}\right)$ in order to feed two Mediterranean sponges species (Ircinia oros and Aplysina cavernicola) and to be able to evaluate their accumulation capacities of each element. 


\section{Materials and Methods}

\section{Organisms}

Specimens of Aplysina cavernicola and Ircinia variabilis were collected off the Fontvieille harbour at St Nicolas rocks in Monaco by SCUBA in March 2012 (lat: 43 43' 36.768"; long: $\left.7^{\circ} 25^{\prime} 25.248^{\prime \prime}\right)$. Immediately after collection, sponges were kept in seawater at constant temperature during their transfer to the aquaria within $30 \mathrm{~min}$. At the IAEA premises, sponges were placed in a 20-L glass aquarium containing $1 \mu \mathrm{m}$ filtered and UV sterilized natural seawater (seawater flux: $40 \mathrm{~L} \mathrm{~h}^{-1}$; temperature $17^{\circ} \mathrm{C} ; 38$ p.s.u.; light/dark cycle $12 \mathrm{~h} / 12 \mathrm{~h}$ ) and acclimated for one week before experiment and fed daily with live Isochrysis galbana.

Aplysina cavernicola (Class: Demospongiae, Order: Verongida, Family: Aplysinidae) is a yellow digitate-shaped sponge, organized in one or more chimney-like structures. I. oros harboured abundant and phylogenetically diverse symbiont consortia including Gammaproteobacteria (Erwin et al., 2011). Numerous inhalant oscula pump water to the central atrium structure and then to the apical exhalent osculum (Pfannkuchen et al., 2009). The close species Aplysina aerophoba displays a clearance rate of $3-18 \mathrm{ml} \cdot \mathrm{g}^{-1} \cdot \mathrm{min}^{-1}$ (Hoffmann et al., 2008).

Ircinia variabilis (Class: Demospongiae, Order: Dictyoceratida, Family: Irciniidae) is a massive sponge. Among the large amounts of symbiotic bacteria hosted by A. cavernicola, gamma-proteobacteria are the second most abundant (Friedrich et al., 1999). Oscules are large and located at the top of the conical lobes. This species does not have mineral spicules but a dense fiber skeleton structurally diverse from classical spongins (Junqua et al., 1974). The clearance rate for this species has been estimated experimentally (data not shown) to $c a .0 .8$ $\mathrm{ml} \cdot \mathrm{g}^{-1} \cdot \mathrm{min}^{-1}$.

\section{Bacteria radiolabelling}

The marine bacteria Pseudomonas stutzeri, belong to the class of gamma-proteobacteria and is distributed widely in the water column and in sediment (Lalucat et al., 2006). Gammaproteobacteria is one of the most abundant bacterial taxa symbiotic of sponges (Webster and Taylor, 2012) and P. stutzeri has been previously identified in intertidal marine sponge (Zhang et al., 2013). In the present study, P. stutzeri have been cultured in a medium radiolabelled with ${ }^{110 \mathrm{~m}} \mathrm{Ag},{ }^{109} \mathrm{Cd}$ (Amersham, UK) and ${ }^{241} \mathrm{Am},{ }^{57} \mathrm{Co},{ }^{134} \mathrm{Cs},{ }^{54} \mathrm{Mn}$ and ${ }^{65} \mathrm{Zn}$ (Isotope Product Laboratory, USA) and then used as trophic source of radioisotope to sponges specimen. 
In detail, P. stutzeri isolates have been first grown for $48 \mathrm{~h}$ by adding bacteria in $5 \mathrm{ml}$ of previously sterilized autoclaved bacterial liquid culture medium (Marine Broth 2216, Difco ${ }^{\mathrm{TM}}$ ) and kept in the dark at $4^{\circ} \mathrm{C}$. Then, the $5 \mathrm{ml}$ culture was transferred in $300 \mathrm{ml}$ of culture medium radiolabelled with $13 \mathrm{kBq} \cdot \mathrm{l}^{-1}$ of ${ }^{110 \mathrm{~m}} \mathrm{Ag}, 7 \mathrm{kBq} \cdot \mathrm{l}^{-1}$ of ${ }^{241} \mathrm{Am}, 39 \mathrm{kBq} \cdot \mathrm{l}^{-1}$ of ${ }^{109} \mathrm{Cd}, 11 \mathrm{kBq} \cdot \mathrm{l}^{-1}$ of ${ }^{57} \mathrm{Co}, 20 \mathrm{kBq} \cdot \mathrm{l}^{-1}$ of ${ }^{134} \mathrm{Cs}, 11 \mathrm{kBq} \cdot \mathrm{l}^{-1}$ of ${ }^{54} \mathrm{Mn}$ and $11 \mathrm{kBq} \cdot \mathrm{l}^{-1}$ of ${ }^{65} \mathrm{Zn}$ and kept in the dark at $25^{\circ} \mathrm{C}$ for $48 \mathrm{~h}$. The culture media has been performed in triplicate.

At the end of the incubation period, bacteria were concentrated by centrifugation $(3000 \mathrm{rpm}$ during $10 \mathrm{~min}$ at $25^{\circ} \mathrm{C}$ ) in order to remove the radiolabelled culture media, without causing destruction of bacteria. The supernatant was discarded and the bacteria were resuspended in $0.2 \mu \mathrm{m}$-filtered seawater and centrifugated again. The operation was repeated three times until no significant radioisotopes activities were detected in the supernatants. Finally, the pellet was resuspended in $50 \mathrm{ml}$ of filtered seawater giving a suspension of living bacteria with a concentration of $2.10^{7} \pm 3.10^{5}$ cell. $\mathrm{ml}^{-1}$. One aliquot of this bacterial solution was radiocounted in order to assess the bioaccumulation of radiotracer in P. stutzeri.

\section{Bacterial concentration assessment}

The concentrations of radiolabelled cells in the bacterial suspension and in the experimental tanks were assessed through the optical density. Measured absorbance values $\left(\mathrm{A}_{680 \mathrm{~nm}}\right)$ have been transformed in bacteria concentration (cell. $\mathrm{ml}^{-1}$ ) thanks to a calibration curve (Figure 1) realized from successive dilutions of the bacterial suspension. The concentration of bacteria in diluted samples has been determined by cytometry. Briefly, bacterial suspensions were stained with Sybr Green I (1/10000 final concentration, Invitrogen) and incubated for 15 minutes in the dark. Samples were analyzed with a FACS CantoII (BDBiosciences) equipped with an air-cooled, $20 \mathrm{~mW}$ solid state blue laser $(488 \mathrm{~nm})$ at low speed $(\sim 8 \mu \mathrm{L} / \mathrm{min})$ during 1 minute. Stained cells were discriminated according to green fluorescence (FL1) from Sybr Green I staining and side scatter properties (SSC) in log mode. Accurate cell concentrations were performed using TruCount beads (BDBiosceinces).

Feeding procedure: the dietary uptake of metals in sponges has been assessed using the pulsechase feeding method (organisms were dietary exposed to radiotracers only once, in order to analyse metal assimilation and depuration from one ration; Warnau et al., 1996). For each sponge species, three individuals were placed individually in $450 \mathrm{ml}$ plastic box (seawater flux: $20 \mathrm{~L} \mathrm{~h}^{-1}$; temperature: $17^{\circ} \mathrm{C}$; salinity 38 p.s.u.; light/dark cycle $12 \mathrm{~h} / 12 \mathrm{~h}$ ) $24 \mathrm{~h}$ before the 
start of the experiment. Then, the water flow renewal has been closed and the radiolabelled bacteria have been resuspended in the seawater until reaching a cell density of $3.10^{7}$ cell. $\mathrm{ml}^{-1}$. Sponges were left for one hour in closed-circuit tanks allowing them to feed with radiolabelled bacteria. After 20 and $60 \mathrm{~min}$, the retention of bacteria by sponges has been assessed by measuring the bacteria concentration in seawater $\left(\mathrm{A}_{680 \mathrm{~nm}}\right)$.

Following this one-hour exposure period, sponges were sampled, rinsed in clean seawater, and immediately counted. Then, sponges were placed in a 20-1 tank with clean seawater (seawater flux: $40 \mathrm{~L} \mathrm{~h}^{-1}$; temperature $17^{\circ} \mathrm{C}$; 38 p.s.u.; light/dark cycle $12 \mathrm{~h} / 12 \mathrm{~h}$ ) and the radiotracers loss in sponges has been followed by counting individuals every days for the first week and every third days during the next four weeks.

\section{Radioanalyses and data treatment}

Radioactivities were measured using a high-resolution $\gamma$-spectrometry system consisting of four coaxial Germanium (N- or P-type) detectors (EGNC 33-195-R, Canberra ${ }^{\circledR}$ and Eurysis ${ }^{\circledR}$ ) connected to a multi-channel analyzer and a computer equipped with a spectra analysis software (Interwinner ${ }^{\circledR} 6$ ). The detectors were calibrated with an appropriate standard for each counting geometry used and measurements were corrected for background and physical decay of the radiotracers.

The bioaccumulation of each radiotracer in bacteria was expressed in concentration factors, which is the ratio between radiotracer activity in the bacteria $-\mathrm{Bq} \mathrm{g}^{-1}-$ and the timeintegrated activity in Marine Broth culture medium $-\mathrm{Bq} \mathrm{g}^{-1}$. The concentration of radiotracers expressed in $\mathrm{Bq}$ cell ${ }^{-1}$ has been transformed using the bacteria mass value of Pseudomonas putida of $5 \cdot 10^{-14} \mathrm{~g} \mathrm{dw} \cdot \mathrm{gell}^{-1}$ (Troussellier et al., 1997).

The radiotracer depuration kinetics in sponges was expressed in terms of change in percentage of remaining activity and was best by either a single- or a double-exponential equation (see Lacoue-Labarthe et al., 2009 for detailed procedure).

Constants (and their statistics) of the best fitting uptake and depuration kinetic equations (decision based on ANOVA tables for two fitted model objects) were estimated by iterative adjustment of the models using the $n l s$ curve-fitting routine in $\mathrm{R}$ freeware (R Core Team, 2014). The level of significance for statistical analyses was always set at $\alpha=0.05$.

\section{Results}




\section{Radiolabelling of Pseudomonas stutzeri}

The culture of the bacteria $P$. stutzeri in a bacterial culture medium radiolabelled with dissolved radiotracers allowed a significant bioaccumulation in bacteria cells of ${ }^{110 \mathrm{~m}} \mathrm{Ag}$, ${ }^{241} \mathrm{Am},{ }^{109} \mathrm{Cd},{ }^{57} \mathrm{Co},{ }^{134} \mathrm{Cs},{ }^{54} \mathrm{Mn}$ and ${ }^{65} \mathrm{Zn}$ after 48 hours of growth (Figure 2). It is noteworthy that bioaccumulation efficiency varied among elements with the highest CF values observed for the non-essential metals ${ }^{110 \mathrm{~m}} \mathrm{Ag}$ and ${ }^{109} \mathrm{Cd}\left(1.10^{7} \pm 4.10^{5}\right.$ and $1.10^{7} \pm 5.10^{5}$, respectively) and the radionuclide ${ }^{241} \mathrm{Am}\left(5 \cdot 10^{6} \pm 3 \cdot 10^{5}\right)$. Contrasting to this, the essential elements ${ }^{65} \mathrm{Zn}$, ${ }^{57} \mathrm{Co}$ and ${ }^{54} \mathrm{Mn}$ have been taken up 3, 20 and 30-fold lower, respectively, in bacteria than ${ }^{110 \mathrm{~m}} \mathrm{Ag}$ and ${ }^{109} \mathrm{Cd}$. Caesium reached a $\mathrm{CF}$ value of $2 \cdot 10^{6} \pm 6 \cdot 10^{4}$.

\section{Radiotracer trophic transfer from bacteria to sponges}

During the one-hour pulse-chase feeding experiment, the monitoring of the absorbance (680 $\mathrm{nm}$ ) of tank seawater allowed at determining the bacterial retention by both species. Thus, after one hour, the three individuals of Aplysina cavernicola removed 20, 45 and $65 \%$ of bacteria suspended in seawater, whereas no significant decrease of bacterial concentration was observed in Ircinia oros tanks, suggesting a lower filtration activity of this species in our experimental condition.

At the end of trophic exposure, the activities of radiotracers accumulated by Aplysina cavernicola (Bq.g ${ }^{-1} \mathrm{dw}$ ) were ranked as followed: ${ }^{109} \mathrm{Cd} \gg{ }^{110 \mathrm{~m}} \mathrm{Ag}>{ }^{241} \mathrm{Am} \approx{ }^{65} \mathrm{Zn}>>{ }^{57} \mathrm{Co}>$ ${ }^{134} \mathrm{Cs}>{ }^{54} \mathrm{Mn}$ (Figure 3A), whereas only ${ }^{109} \mathrm{Cd}>>{ }^{110 \mathrm{~m}} \mathrm{Ag}>{ }^{65} \mathrm{Zn}$ were significantly detected in Ircinia oros. This pattern of bioaccumulation is congruent with the radioactivity levels measured in bacteria for each element, showing that A. cavernicola took up around $60 \%$ of radiotracers (Figure $3 \mathrm{~B}$ ) accumulated in bacteria except ${ }^{134} \mathrm{Cs}$ for which only $8 \%$ has been transferred from bacteria to sponge. Contrasting to this, I. oros retained only $7 \%$ of ${ }^{110 \mathrm{~m}} \mathrm{Ag}$, ${ }^{109} \mathrm{Cd}$ and ${ }^{65} \mathrm{Zn}$ counted in bacteria.

Following the 1-h pulse chase feeding, the whole-body depuration for ${ }^{110 \mathrm{~m}} \mathrm{Ag},{ }^{241} \mathrm{Am},{ }^{109} \mathrm{Cd}$, ${ }^{57} \mathrm{Co},{ }^{54} \mathrm{Mn}$ and ${ }^{65} \mathrm{Zn}$ was followed for 35 days in both sponge species. The ${ }^{134} \mathrm{Cs}$ loss kinetic was not shown as this radionuclide activity has been found below the detection limit in sponge placed in clean seawater after 24 hours, suggesting a rapid depuration of this element. The depuration kinetics in Aplysina cavernicola were best fitted by a two-compartment model for all element except ${ }^{54} \mathrm{Mn}$ loss better fitted by a single-compartment model (Figure 4 and 5; Table 1). Both ${ }^{110 \mathrm{~m}} \mathrm{Ag}$ and ${ }^{241} \mathrm{Am}$ were the most rapidly depurated by sponge with $88 \pm 3$ and $79 \pm 8 \%$ lost with a biological half-life $\left(\mathrm{T}_{\mathrm{b}^{1 / 2}}\right)$ of 1 and $1.5 \mathrm{~d}$, respectively. The essential 
elements displayed the highest assimilation efficiency for the long lived components $\left(\mathrm{A}_{01}=\right.$ 55,95 and $62 \%$ for ${ }^{57} \mathrm{Co},{ }^{54} \mathrm{Mn}$ and ${ }^{65} \mathrm{Zn}$, respectively, with relatively short $\mathrm{Tb}_{1 / 2}$ comprised between 12 and $18 \mathrm{~d}$. Contrasting to this, $33 \%$ of ${ }^{110 \mathrm{~m}} \mathrm{Ag}, 57 \%$ of ${ }^{109} \mathrm{Cd}$ and $63 \%$ of ${ }^{65} \mathrm{Zn}$ significantly accumulated by Ircinia oros displayed longer $\mathrm{T}_{\mathrm{b}^{1 / 2}}(41,57$ and $33 \mathrm{~d}$, respectively), implying a better efficient and longer retention of these elements by sponge tissues or within their aquifer system.

\section{Discussion}

The paper first reports that bacteria $P$. stutzeri efficiently bioaccumulated trace elements in our culture experimental conditions with CF comprised between $10^{5}$ and $10^{7}$ after 48 hours of growth in radiolabeled medium. Similar high bioaccumulation efficiencies have been already reported in picoplankton Synechococcus sp (Fisher, 1985), under similar exposure conditions. The small size of bacteria and the subsequent high surface/volume ratio are argued as the main explanation fostering the uptake capacities. Basically, two main processes drive the trace element uptake in microorganisms, i.e. the adsorption of metal on the particle walls and external materials such as the exopolysaccharides, and the absorption in cells through ionic transporters (Gadd, 1990).

The gram-negative wall of $P$. stutzeri and its associated negative charges might favour the binding of metallic cations (Gadd et al., 1989). For each element, the adsorption on bacterial surface could be estimated through the partition coefficient between particles and seawater $\left(\mathrm{K}_{\mathrm{d}}\right)$ reported in the literature. According to available data on particles or phytoplankton, the particle reactivity among studied elements decreases according to ${ }^{241} \mathrm{Am}>\mathrm{Mn}>\mathrm{Zn}>\mathrm{Ag}>$ Co > Cd > Cs (Wang et al., 1996; Keung et al., 2008; Metian et al., 2008a; Metian et al., 2009). This ranking is not congruent with the CF values observed in this study, especially in the case of $\mathrm{Ag}$ and $\mathrm{Cd}$ supposed to be less bound on bacterial surface, but here highly accumulated on P. stutzeri.

In cells of Pseudomonas aeruginosa, high $\mathrm{Hg}$ uptake in strain has been attributed to cysteinerich transport proteins carrying metal from external medium to cytoplasm (Chang and Hong, 1994). Similar mechanisms might be expected to contribute to the high accumulation of Ag, and to a lesser extent $\mathrm{Cd}$, according to the affinity of these metals for sulfhydryl-rich group (Bell and Kramer, 1999). Moreover, some bacteria strains are known for their high resistance to silver toxicity (Haefeli et al., 1984; Li et al., 1997). While this resistance seems to be 
associated with energy-dependent ion efflux ( $\mathrm{Li}$ et al., 1997) in most of studied bacteria (e.g. Escherichia coli), it has been demonstrated that the strain Pseudomonas stutzeri AG259 accumulated Ag under a metal-based single crystal, precipitating then high Ag concentration under non-metabolically available form (Klaus et al., 1999).

Regarding Cd, Chang et al. (1997) highlighted a rapid adsorption of the element on cells, but a difference of biosorption capacity between inactivated and free cells, suggesting that a metabolic-dependent absorption occurs in this strain. Furthermore, same authors showed that cells at exponential growth phase exhibited higher $\mathrm{Cd}$ adsorption capacities, suggesting that in our radiolabelling conditions, the culture of $P$. stutzeri in a ${ }^{109} \mathrm{Cd}$ radiolabelled medium could contribute to reach high $\mathrm{CF}$ value.

In the present study, it is noteworthy that essential elements (i.e. ${ }^{57} \mathrm{Co},{ }^{54} \mathrm{Mn}$, and ${ }^{65} \mathrm{Zn}$ ) displayed lower $\mathrm{CF}$ values than ${ }^{110 \mathrm{~m}} \mathrm{Ag},{ }^{241} \mathrm{Am}$ and ${ }^{109} \mathrm{Cd}$. The microorganisms such as bacteria are known to synthesize secondary metabolites, called "siderophores", that play a key role in the essential metal homeostasis (Lalucat et al., 2006). Indeed, some bacteria strains produce low-molecular-weight chelators with a high affinity for Fe and other transition metals to bind them in the extracellular environment and transport them inside the cells (Zawadzka et al., 2006). In Pseudomonas aerunginosa, salicylate-derived pyochelin seems to have a key role in supplying divalent metals such as Co or Ni, but displays a low affinity for Mn (Visca et al., 1992), suggesting that siderophore unlikely contribute to the uptake of this element. Some P. stutzeri strains produce deferrioxamine or PDTC (pyridine-2,6-bisthiocarboxylate) siderophores (Lewis et al., 2004) also known for their role in transition element nutrition as demonstrated for the $\mathrm{Zn}$ (Leach et al., 2007). However, information are lacking on the various affinity of siderophores for the essential transition metals to better assess their role in metal metabolism.

Additionally, it is important to remind that Pseudomonas stutzeri were cultured in a medium (Marine Broth 2216; (Zobell, 1941)), which contains essential compounds and nutrients for an optimal bacteria growth. Yeast extract supplies trace element and may contribute to lower the bioaccumulation efficiency of essential metals. According to Grant and Pramer (1962), $\mathrm{Mn}$ and Co concentrations are almost one order of magnitude lower than those of $\mathrm{Zn}$ (3 and $3.5 \mu \mathrm{g} . \mathrm{g}^{-1}$ vs. $\left.75 \mu \mathrm{g} . \mathrm{g}^{-1} \mathrm{dw}\right)$ but similar to the Cd concentration $\left(\sim 1.5 \mu \mathrm{g} . \mathrm{g}^{-1} \mathrm{dw}\right)$. Considering that addition of stable element in culture medium may lowers concentration factor (Metian et al., 2008b), the yeast extract composition would contribute to explain surprising lower CF values observed for essential elements such as Co and Mn, compared to non-essential element 
or radionuclide, such as Cs, known to be poorly accumulated in marine invertebrates and microorganisms (Wang et al., 1996; Pouil et al., 2015)..

Tissues of Mediterranean sponges fed with radiolabeled bacteria during one hour present an activity pattern of the seven radiotracers similar to bacterial pattern (Figure 3A). Aplysina cavernicola displayed around $60 \%$ of the radioactivities (no significant difference among radiotracers except ${ }^{134} \mathrm{Cs}$; U-test; $\mathrm{p}>0.05$ ) added through bacteria whereas Ircinia oros only accumulated around $7 \%$. This contrasting bacterial metal transfer between both species is likely due to the low clearance rate of the massive I. oros being 4-22 fold lower than this of the branching erect $A$. cavernicola (Hoffmann et al., 2008). Thus, this estimation is congruent with the 9-fold difference of radiotracers activities counted in both species. As a result, only the elements highly accumulated in P. stutzeri, i.e. $\mathrm{Ag}, \mathrm{Cd}$ and $\mathrm{Zn}$, reached activities levels in sponge above the detection threshold, limiting the assessment of trophic transfer behaviour for the others radionuclides.

It is noteworthy that, in A. cavernicola, a low fraction of ${ }^{134} \mathrm{Cs}$ contained in bacteria, i.e. $8 \pm 3$ $\%$ vs. $43 \pm 24 \%, 74 \pm 15 \%, 63 \pm 23 \%, 63 \pm 25 \%, 51 \pm 19 \%$ and $57 \pm 21 \%$ for ${ }^{54} \mathrm{Mn},{ }^{57} \mathrm{Co}$, ${ }^{65} \mathrm{Zn},{ }^{110 \mathrm{~m}} \mathrm{Ag},{ }^{109} \mathrm{Cd}$, and ${ }^{241} \mathrm{Am}$, respectively; U-test; $\left.\mathrm{p}<0.05\right)$ has been transferred to the sponge, suggesting a rapid depuration of this element by bacteria and sponge during the one hour pulse feeding chase. Indeed, Cs is a soluble element, known as a mimetic of $\mathrm{K}$ (Wang et al., 2000), implying both rapid uptake in cells and then loss in seawater, following water movements between both compartments (Lacoue-Labarthe et al., 2010).

Kinetic parameters following pulse-chase feeding (Figure 4 and 5; Table 1) suggest that depurations of all element except $\mathrm{Mn}$ were best fitted by a two-compartment models, implying that 1) a fraction is rapidly lost likely depending on the water renewal in the sponge aquifer system, and that 2) another fraction of metals remained longer associated to sponge tissue through retention of bacteria in the aquifer system or assimilation of elements in sponge tissues. Results clearly show that the longest $\mathrm{T}_{\mathrm{b}^{1 / 2}}$ is around 2 weeks in A. cavernicola whatever the metal, highlighting a poor retention of metals following particulate contamination. In comparison, $\mathrm{T}_{\mathrm{b}^{1 / 2}}$ of elements accumulated from waterborne pathway were between 2 and 10-fold longer (with 35 and 157 days for ${ }^{241} \mathrm{Am}$ and ${ }^{109} \mathrm{Cd}$, respectively) in the branch erect sponge Axinella reniformis (Genta-Jouve et al., 2012). Moreover, calculated $\mathrm{T}_{\mathrm{b}^{1 / 2}}$ in this study for all elements exceeds one month in Ircina oros for Ag, $\mathrm{Cd}$ and $\mathrm{Zn}$. Again, the contrasting clearance rates between both species could be one explanation of this difference, implying that the water renewal in the aquifer system drive the depuration rate for absorbed or 
assimilated trace elements in sponge. Thus, this work highlighted that the high pumping flow reported in erect sponge $A$. cavernicola contributed to a rapid accumulation of radiolabelled particles compared to the slow filter feeder massive sponge I. oros (Turon et al., 1997), but foster also a rapid depuration of trace elements, suggesting a limited net accumulation of metals from trophic route for this species. This observation is congruent with the bioaccumulation capacities of dissolved metals in Mediterranean sponges showing that with massive sponges (Chondrosia reniformis, Agelas oroides and Ircina variabilis) display the highest uptake and retention capacities compared to erect species (Acanthella acuta, Axinella damicornis, Axinella verrucosa). These massive species possess higher choanocyte chamber volumes and consequently a much higher area to bind trace elements or retained contaminated particles as suggested by Cebrian and colleagues (2007b).

This study demonstrated experimentally that filtered marine bacteria by Mediterranean sponges could be considered as a biotic vector of metal transfer along the trophic web. However, many questions merged from these results for enhancing our understanding of the observed metal transfer from microoganisms to sponges and the interspecific differences of bioaccumulation capacities among sponges. Further experiments including subcellular fractionation could help to describe the trace element bioaccumulation pathways in bacteria (adsorption vs. absorption) and thus provide some indications on the metal bioaccessibility for the next trophic level. Moreover, the bioaccumulation efficiencies through particulate pathway differs between the two studied species, likely linked to their massive vs. erect structure and their respective pumping and clearance capacities (de Mestre et al., 2012). Considering the potential use of sponges as "biomonitors", the massive I. oros requests a prolonged metal input to reveal a contamination of bacterial resources, but retains more longer this information compared to erect A. cavernicola. In other terms, the first species seems to be appropriate to detect chronic contamination compared to the erect sponge. Nevertheless, beyond these characteristics, the role of symbiotic microorganisms in the particle retention, digestion and assimilation of nutrients and trace elements remains unknown. Both A. cavernicola and I. oros are considered as HMA (High Microbial Abundance) sponge species (Taylor et al., 2007; Weisz et al., 2008; Erwin et al., 2011). Thus, the interspecific bioaccumulation differences cannot be inferred to microbial density but rather potentially to distinct microbial communities according to sponge species (Selvin et al., 2009). Additionally, only one bacteria strain has been used in this work, implying that only one particle size has been investigated as a potential vector for metal trophic transfer. Sponges 
however show adaptive interspecific variation with respect to clearance rate and particle size selection (Turon et al., 1997). Further studies investigating trophic bioaccumulation on a large range of particle size using other bacterial strains or picoplankton could be valuable to define the contribution of filtered particles in the bioaccumulation of metals in these biomonitors of growing interest (Patel et al., 1984; Pérez et al., 2005b; Cebrian et al., 2007b). Finally, we hope that this study will revive some interest on the bacterivory as a pathway for metal integration in trophic web.

\section{Acknowledgement}

The IAEA is grateful for the support provided to its Environment Laboratories by the Government of the Principality of Monaco. We thank Olivier Thomas from the University of Nice to provide with sponge specimen, and Sophie Sable from the University of La Rochelle to offer the bacteria strain of Pseudomonas stutzeri. We are grateful to the cytometry and imaging platform that provided organization and service of the UMR 7266 LIENSs, University of La Rochelle and CNRS. Authors thank the two anonymous reviewers for their comments and fruitful suggestions improving the manuscript.

\section{References}

Batista, D., Muricy, G., Chávez Rocha, R., Miekeley, N.F., 2014. Marine sponges with contrasting life histories can be complementary biomonitors of heavy metal pollution in coastal ecoystems. Environmental Science of Pollution Research 21, 5784-5794.

Bell, R.A., Kramer, J.R., 1999. Structural chemistry and geochemistry of silver-sulfur compounds: critical review. Environ Toxicol Chem 18, 9-22.

Brierley, C.S., 1990. Bioremediation of metal-contaminated surface and ground-water. Geomicrobiology Journal 8, 201-223.

Cebrian, E., Uriz, J.M., Turon, X., 2007a. Sponges as biomonitors of heavy metals in spatial and temporal surveys in northwestern mediterranean: multispecies comparison. Environ. Toxicol. Chem. 26, 2430-2439.

Cebrian, E., Uriz, M.J., Turon, X., 2007b. Sponges as biomonitors of heavy metals in spatial and temporal surveys in northwestern Mediterranean: Multispecies comparison. Environ Toxicol Chem 26, 2430-2439.

Chang, J.-S., Hong, J., 1994. Biosorption of mercury by the inactivated cells of Pseudomonas aeruginosa PU21 (Rip64). Biotechnol Bioeng 44, 999-1006.

Chang, J.-S., Law, R., Chang, C.-C., 1997. Biosorption of lead, copper and cadmium by biomass of Pseudomonas aeruginosa PU21. Water Res 31, 1651-1658.

Coma, R., Ribes, M., Gili, J.M., Hughes, R.N., 2001. The ultimate opportunits: consumers of seston. Mar. Ecol. Prog. Ser. 219, 305-308. 
Conti, M.E., Iacobucci, M., 2008. Marine organisms as biomonitors. in: Conti, M.E. (Ed.). Biological monitoring: theory and applications. WIT Press, Roma, pp. 81-110.

de Goeij, J., van Oevelen, D., Vermeij, M.J.A., Osinga, R., Middelburg, J.J., de Goeij, A.F.P.M., Admiraal, W., 2013. Surviving in a Marine desert: the sponge loop retains resources within coral reefs. Science 342, 108-110.

De Goeij, J.M., van der Berg, H., van Oosten, M.M., Epping, E.G.H., van Duyl, F.C., 2008. Major bulk dissolved organic carbon (DOC) removal by encrusting coral reef cavity sponges. Mar. Ecol. Prog. Ser. 357, 139-151.

de Mestre, C., Maher, W., Roberts, D., Broad, A., Krikowa, F., Davis, A.R., 2012. Sponges as sentinels: Patterns of spatial and intra-individual variation in trace metal concentration. Mar Pollut Bull 64, 80-89.

Erwin, P.M., Olson, J.B., Thacker, R.W., 2011. Phylogenetic diversity, host-specificity and community profiling of sponge-associated bacteria in the Northern Gulf of Mexico. PLoS ONE 6, e26806.

Fisher, N.S., 1985. Accumulation of metals by marine picoplankton. Mar Biol 87, 137-142.

Friedrich, A.B., Merkert, H., Fendert, T., Hacker, J., Proksch, P., Hentschel, U., 1999. Microbial diversity in the marine sponge Aplysina cavernicola (formerly Verongia cavernicola) analyzed by fluorescence in situ hybridization (FISH). Mar Biol 134, 461-470.

Gadd, G.M., 1990. Heavy metal accumulation by bacteria and other microorganisms. Experientia 46, 834-840.

Gadd, G.M., Laurence, O.S., Briscoe, P.A., Trevors, J.T., 1989. Silver accumulation in Pseudomonas stutzeri AG259. Biol Metals 2, 168-173.

Genta-Jouve, G., Cachet, N., Oberhänsli, F., Noyer, C., Teyssié, J.-L., Thomas, O.P., LacoueLabarthe, T., 2012. Comparative bioaccumulation kinetics of trace elements in Mediterranean marine sponges. Chemosphere 89, 340-349.

Grant, C.L., Pramer, D., 1962. Minor element composition of yeast extract. J Bacteriol 84, 869-870.

Hadas, E., Marie, D., 2006. Virus predation by sponges is a new nutrient-flow pathway in coral reef food webs. Limnol. Oceanogr. 51, 1548-1550.

Haefeli, C., Franklin, C., Hardy, K., 1984. Plasmid-determined silver resistance in Pseudomonas stutzeri isolated from a silver mine. J Bacteriol 158, 389-392.

Hansen, I.V., Weeks, J.M., Depledge, M.H., 1995. Accumulation of copper, zinc, cadmium and chromium by the marine sponge Halichondria paniciea Pallas and the implications for biomonitoring. Mar. Pollut. Bull. 31, 133-138.

Hentschel, U., Usher, K.M., Taylor, M.W., 2006. Marine sponges as microbial fermenters. FEMS Microbiol. Ecol. 55, 167-177.

Hoffmann, F., Røy, H., Bayer, K., Hentschel, U., Pfannkuchen, M., Brîmmer, F., Beer, D.d., 2008. Oxygen dynamics and transport in the Mediterranean sponge Aplysina aerophoba. Mar Biol 153, 1257-1264.

Iyer, A., Mody, K., Jha, B., 2005. Biosorption of heavy metals by a marine bacterium. Mar. Pollut. Bull., 340-343.

Junqua, S., Robert, L., Garrone, R., De Ceccatty, M.P., Vacelet, J., 1974. Biochemical and morphological studies on collagens of horny sponges. Ircinia filaments compared to spongines. Connective Tissue Research 2, 193-203.

Keung, C.F., Guo, F., Qian, P., Wang, W.X., 2008. Influences of metal-ligand complexes on the cadmium and zinc biokinetics in the marine bacterium, Bacillus firmus. Environ Toxicol Chem 27, 131-137.

Klaus, T., Joerger, R., Olsson, E., Granqvist, C.-G., 1999. Silver-based crystalline nanoparticles, microbially fabricated. Proc Natl Acad Sci U S A 96, 13611-13614. 
Kowalke, J., 2000. Ecology and energetics of two Antarctic sponges. J. Exp. Mar. Biol. Ecol. 247, 85-97.

Lacoue-Labarthe, T., Warnau, M., Oberhänsli, F., Teyssié, J.-L., Bustamante, P., 2009. Bioaccumulation of inorganic $\mathrm{Hg}$ by the juvenile cuttlefish Sepia officinalis exposed to ${ }^{203} \mathrm{Hg}$ radiolabelled seawater and food. Aquat Biol 6, 91-98.

Lacoue-Labarthe, T., Warnau, M., Oberhänsli, F., Teyssié, J.-L., Bustamante, P., 2010. Contrasting accumulation biokinetics and distribution of ${ }^{241} \mathrm{Am}, \mathrm{Co}, \mathrm{Cs}, \mathrm{Mn}$ and $\mathrm{Zn}$ during the whole development time of the eggs of the common cuttlefish, Sepia officinalis. J Exp Mar Biol Ecol 382, 131-138.

Lalucat, J., Bennasar, A., Bosch, R., Garciá-Valdés, E., Palleroni, N.J., 2006. Biology of Pseudomonas stutzeri. Microbiol Mol Biol Rev 70, 510-547.

Leach, L.H., Morris, J.C., Lewis, T.A., 2007. The role of the siderophore pyridine-2,6-bis (thiocarboxylic acid) (PDTC) in zinc utilization by Pseudomonas putida DSM 3601. Biometals 20, 717-726.

Lewis, T.A., Leach, L., Morales, S., Austin, P.R., Hartwell, H.J., Kaplan, B., Forker, C., Meyer, J.-M., 2004. Physiological and molecular genetic evaluation of the dechlorination agent, pyridine-2,6-bis(monothiocarboxylic acid) (PDTC) as a secondary siderophore of Pseudomonas. Environmental Microbiology 6, 159-169.

Li, X.Z., Nikaido, H., Williams, K.E., 1997. Silver-resistant mutants of Escherichia coli display active efflux of $\mathrm{Ag}^{+}$and are deficient in porins. J Bacteriol 179, 6127-6132.

Luoma, S.N., 1990. Processes affecting metal concentrations in estuarine and coastal marine sediments. in: Furness, R.W., Rainbow, P.S. (Eds.). Heavy metals in the marine environment. CRC Press, Boca Raton, pp. 51-66.

Malik, A., 2004. Metal bioremediation through growing cells. Environment International 30, 261-278.

Metian, M., Bustamante, P., Cosson, R.P., Hédouin, L., Warnau, M., 2008a. Investigation of Ag in the king scallop Pecten maximus using field and laboratory approaches. J Exp Mar Biol Ecol 367, 53-60.

Metian, M., Bustamante, P., Hédouin, L., Oberhänsli, F., Warnau, M., 2009. Delineation of heavy metal uptake pathways (seawater and food) in the variegated scallop Chlamys varia, using radiotracer techniques. Mar Ecol Prog Ser 375, 161-171.

Metian, M., Giron, E., Borne, V., Hédouin, L., Teyssié, J.-L., Warnau, M., 2008b. The brown alga Lobophora variegata, a bioindicator species for surveying metal contamination in tropical marine environments. J Exp Mar Biol Ecol 362, 49-54.

Patel, B., Balani, M.C., Patel, S., 1985. Sponge "sentinel" of heavy metals. Sci. Total Environ. 41, 143-152.

Patel, B., Patel, S., Taylor, D.M., 1984. The chemical form of cobalt-60 in the marine sponge Spirastrella cuspidifera. Mar Biol 80, 45-48.

Pérez, T., Longet, D., Schembri, T., Rebouillon, P., Vacelet, J., 2005a. Effects of 12 years' operation of a sewage treatment plant on trace metal occurence within a Mediterranean commercial sponge (Spongia officinalis, Desmospongiae). Mar. Pollut. Bull. 50, 301-309.

Pérez, T., Longet, D., Schembri, T., Rebouillon, P., Vacelet, J., 2005b. Effects of 12 years' operation of a sewage treatment plant on trace metal occurrence within a Mediterranean commercial sponge (Spongia officinalis, Demospongiae). Mar Pollut Bull 50, 301-309.

Pfannkuchen, M., Fritz, G.B., Schlesinger, S., Bayer, K., Brümmer, F., 2009. In situ pumping activity of the sponge Aplysina aerophoba, Nardo 1886. J Exp Mar Biol Ecol 369, 65-71.

Phillips, D.J.H., Rainbow, P.S., 1993. Biomonitoring of Trace Aquatic Contaminants. Applied Science Publishers, Barking.

Pile, A.J., Patterson, M.R., Witman, J.D., 1996. In situ grazing on plankton $<10 \mu \mathrm{m}$ by the boreal sponge Mycale lingua. Mar. Ecol. Prog. Ser. 141, 95-102. 
Pouil, S., Bustamante, P., Warnau, M., Oberhaënsli, F.o., Metian, M., 2015. Delineation of ${ }^{134} \mathrm{Cs}$ uptake pathways (seawater and food) in the variegated scallop Mimachlamys varia. $\mathrm{J}$ Environ Radioact 148, 74-79.

R Core Team, 2014. R: A language and environment for statistical computing. R Foundation for Statistical Computing, Vienna, Austria.

Rainbow, P.S., 1995a. Biomonitoring of heavy metal availability in the marine environment. Mar Pollut Bull 31, 183-192.

Rainbow, P.S., 1995b. Biomonitoring of heavy metal availability in the marine environment. Mar. Pollut. Bull. 31, 183-192.

Reiswig, H.M., 1981. Partial carbon and energy budgets of the bacteriosponge Verongia fistularis (Porifera, Demospongiae) in Barbados. Mar. Ecol. 2, 273-293.

Ribes, M., Coma, R., Gili, J.M., 1999a. Heterogenous feeding in benthic suspension feeders: the natural diet and grazing rate of the temperate gorgonian Paramuricea clavat (Cnidaria: Octocorallia) over a year cycle. Mar. Ecol. Prog. Ser. 183, 125-137.

Ribes, M., Coma, R., Gili, J.M., 1999b. Natural diet and grazing rate of the temperate sponge Dysidea avara (Desmospongiae, Dendroceratida) throughout an annual cycle. Mar. Ecol. Prog. Ser. 176, 179-190.

Scott, J.A., Palmer, S.J., 1990. Sites of cadmium uptake in bacteria used for biosorption. Applied Microbiology and Biotechnology 33, 221-225.

Selvin, J., Shanmugha Priya, S., Seghal Kiran, G., Thangavelu, T., Sapna Bai, N., 2009. Sponge-associated marine bacteria as indicators of heavy metal pollution. Microbiol Res 164, 352-363.

Taylor, M.W., Radax, R., Steger, D., Wagner, M., 2007. Sponge-associated microorganisms: evolution, ecology, and biotechnological potential. Microbiol Mol Biol Rev 71, 295.

Troussellier, M., Bouvy, M., Courties, C., Dupuy, C., 1997. Variation of carbon content among bacterial species undere starvation condition. Aquat Microb Ecol 13, 113-119.

Trussell, G.C., Lesser, M.P., Patterson, M.R., Genovese, S.J., 2006. Depth-specific differences in growth of the reef sponge Callyspongia vaginalis: role of bottom-up effects. Mar. Ecol. Prog. Ser. 323, 149-158.

Turon, X., Galera, J., Uriz, M.J., 1997. Clearance rates and aquiferous systems in two sponges with contrasting life-history strategies. J Exp Zool 278, 22-36.

Ulrick Riisgård, H., Larsen, P.S., 2010. Particle capture mechanisms in suspension-feeding invertebrates. Mar. Ecol. Prog. Ser. 418, 255-293.

Valls, M., Lorenzo, V.D., 2002. Exploiting the genetic and biochemical capacities of bacteria for the remediation of heavy metal pollution. FEMS Microbiology Reviews 26, 327-338.

Verdenal, B., Diana, C., Amoux, A., Vacelet, J., 1990. Pollutant levels in Mediterranean commercial sponges. in: Rützler, K. (Ed.). New perspective in sponge biology. Smithsonian Institution Press, Washington DC, pp. 516-524.

Visca, P., Colotti, G., Serino, L., Verzili, D., Orsi, N., Chiancone, E., 1992. Metal regulation of siderophore synthesis in Pseudomonas aeruginosa and functional effects of siderophoremetal complexes. Appl Environ Microbiol 58, 2886-2893.

Wang, W.-X., Fisher, N.S., Luoma, S.N., 1996. Kinetic determination of trace element bioaccumulation in the mussel Mytilus edulis. Mar Ecol Prog Ser 140, 91-113.

Wang, W.X., Ke, C., Yu, K.N., Lam, P.K.S., 2000. Modeling radiocesium bioaccumulation in a marine food chain. Mar Ecol Prog Ser 208, 41-50.

Webster, N.S., Taylor, M.W., 2012. Marine sponges and their microbial symbionts: love and other relationships. Environmental Microbiology 14, 335-346.

Webster, N.S., Webb, R.I., Ridd, M.J., Hill, R.T., Negri, A.P., 2001. The effect of copper on the microbial community of a coral reef sponge. Environ. Microbiol. 3, 19-31. 
Weisz, J.B., Lindquist, N., Martens, C., 2008. Do associated microbial abundances impact marine demosponge pumping rates and tissue densities? Oecologia 155, 367-376.

Yahel, G., Sharp, J., Marie, D., Hase, C., Genin, A., 2003. In situ feeding and element removal in the symbiont-bearing sponge Theonella swinhoei: bulk DOC is the major source for carbon. Limnol. Oceanogr. 48, 141-149.

Yahel, G., Whitney, F., Reiswig, H.M., Eerkes-Medrano, D.J., Leys, D.I., 2007. In situ feeding and metabolism of glass sponges (Hexactinellida, Porifera) studied in a deep temperate fjord with a remotely operated submersible. Limnol. Oceanogr. 52, 428-440.

Zawadzka, A.M., Vandecasteele, F.P.J., Crawford, R.L., Paszczynsky, A.J., 2006. Identificiation of siderophores of Pseudomonas stutzeri. Can J Microbiol 52, 1164-1176.

Zhang, J., Cao, X., Xin, Y., Xue, S., Zhang, W., 2013. Purification and characterization of a dehalogenase from Pseudomonas stutzeri DEH130 isolated from the marine sponge Hymeniacidon perlevis. World J Microbiol Biotechnol 29, 1791-1799.

Zhou, Q., Zhang, J., Fu, J., Shi, J., Jiang, G., 2008. Biomonitoring: An appealing tool for assessment of metal pollution in the aquatic ecosystem. Anal Chim Acta 606, 135-150.

Zobell, C.E., 1941. Studies on marine bacteria. I. The cultural requirements of heterotrophic aerobes. J Mar Res 4, 42-75. 


\section{Figures captions}

Figure 1. Calibration curve relating the bacteria concentrations (cell $/ \mathrm{ml}$ ) according to the absorbance at $680 \mathrm{~nm}$.

Figure 2. Concentration factors (CF) of radiotracers in the bacteria Pseudomonas stutzeri cultured during $48 \mathrm{~h}$ in Marine Broth medium radiolabelled with ${ }^{54} \mathrm{Mn}\left(11 \mathrm{~Bq} \cdot \mathrm{ml}^{-1}\right),{ }^{57} \mathrm{Co}(11$ Bq. $\left.\mathrm{ml}^{-1}\right),{ }^{65} \mathrm{Zn}\left(11 \mathrm{~Bq} \cdot \mathrm{ml}^{-1}\right),{ }^{110 \mathrm{~m}} \mathrm{Ag}\left(13 \mathrm{~Bq} \cdot \mathrm{ml}^{-1}\right),{ }^{109} \mathrm{Cd}\left(39 \mathrm{~Bq} \cdot \mathrm{ml}^{-1}\right),{ }^{134} \mathrm{Cs}\left(20 \mathrm{~Bq} \cdot \mathrm{ml}^{-1}\right)$, ${ }^{241} \mathrm{Am}\left(7 \mathrm{~Bq} \cdot \mathrm{ml}^{-1}\right)$.

Figure 3. (A) Radiotracers activities (Bq. $\mathrm{g}^{-1} \mathrm{dw} ; \mathrm{n}=3$ per sponge) and (B) retained activities (\%) measured in sponges Ircina oros (black histogram) and Aplysina cavernicola (grey histogram) after feeding with radiolabelled bacteria Pseudomonas stutzeri $\left(2.9 .10^{7}\right.$ bacteria. $\mathrm{ml}^{-1}$ ) for one hour. Please note the logarithmic scale for the figure (A) and that ${ }^{54} \mathrm{Mn}$, ${ }^{57} \mathrm{Co},{ }^{134} \mathrm{Cs}$ and ${ }^{241} \mathrm{Am}$ activities were under the limit detection in I. oros.

Figure 4. Ircina oros. Loss kinetics of ${ }^{110 \mathrm{~m}} \mathrm{Ag},{ }^{109} \mathrm{Cd}$ and ${ }^{65} \mathrm{Zn}$ (\% remaining activity [RA]; mean $\pm \mathrm{SD}$ ) in the sponge Ircina oros $(\mathrm{n}=3$ ) previously fed with radiolabelled bacteria for one hour. Parameters for the best fitting equations are given in Table 1.

Figure 5. Aplysina cavernicola. Loss kinetics of radiotracers (\% remaining activity [RA]; mean $\pm \mathrm{SD}$ ) in the sponge Aplysina cavernicola $(\mathrm{n}=3)$ previously fed with radiolabelled bacteria for one hour. Parameters for the best fitting equations are given in Table 1. 


\section{Tables}

Table 1. Parameters and statistics of the depuration kinetics of radiotracers in two species of sponge, Ircina oros and Aplysina cavernicola, fed for one hour with radiolabelled bacteria Pseudomonas stutzeri and kept for 36 days in depuration condition.

\begin{tabular}{|c|c|c|c|c|c|c|c|c|c|}
\hline Metal & Species & Model & $\mathrm{A}_{0 \mathrm{~s}} \pm \mathrm{SE}(\%)$ & $\mathrm{k}_{\mathrm{es}}$ & $\mathrm{T}_{\mathrm{b}^{1} / 2 \mathrm{~s}} \pm \mathrm{SE}(\mathrm{d})$ & $\mathrm{A}_{01} \pm \mathrm{SE}(\%)$ & $\mathrm{k}_{\mathrm{el}}$ & $\mathrm{T}_{\mathrm{b}^{1 / 21}} \pm \mathrm{SE}(\mathrm{d})$ & $\mathrm{R}^{2}$ \\
\hline \multirow[t]{2}{*}{${ }^{54} \mathrm{Mn}$} & I. oros & - & - & - & - & - & - & - & \\
\hline & A. cavernicola & $\mathrm{O}$ & - & - & - & $95 \pm 4$ & $0.039 * * *$ & $18 \pm 2$ & 0.887 \\
\hline \multirow[t]{2}{*}{${ }^{57} \mathrm{Co}$} & I. oros & - & - & - & - & - & - & & - \\
\hline & A. cavernicola & $\mathrm{T}$ & $45 \pm 13$ & 0.516 & $1.3 \pm 0.7$ & $55 \pm 13$ & $0.049 * *$ & $14 \pm 4$ & 0.917 \\
\hline \multirow[t]{2}{*}{${ }^{65} \mathrm{Zn}$} & I. oros & $\mathrm{T}$ & $38 \pm 8$ & 1.145 & $0.6 \pm 0.3$ & $63 \pm 5$ & $0.021 * * *$ & $33 \pm 8$ & 0.848 \\
\hline & A. cavernicola & $\mathrm{T}$ & $38 \pm 6$ & $0.652 * * *$ & $1.1 \pm 0.3$ & $62 \pm 5$ & $0.058 * * *$ & $12 \pm 1$ & 0.982 \\
\hline \multirow[t]{2}{*}{${ }^{110 \mathrm{~m}} \mathrm{Ag}$} & I. oros & $\mathrm{T}$ & $52 \pm 4$ & $0.589 * * *$ & $1.2 \pm 0.2$ & $48 \pm 3$ & $0.017 * * *$ & $41 \pm 8$ & 0.974 \\
\hline & A. cavernicola & $\mathrm{T}$ & $88 \pm 3$ & $0.681 * * *$ & $1.0 \pm 0.1$ & $13 \pm 3$ & $0.040 * *$ & $17 \pm 5$ & 0.993 \\
\hline \multirow[t]{2}{*}{${ }^{109} \mathrm{Cd}$} & I. oros & $\mathrm{T}$ & $67 \pm 8$ & $2.258^{*}$ & $0.3 \pm 0.2$ & $33 \pm 3$ & 0.012 & $57 \pm 35$ & 0.860 \\
\hline & A. cavernicola & $\mathrm{T}$ & $53 \pm 5$ & $1.490 * * *$ & $0.5 \pm 0.1$ & $47 \pm 3$ & $0.039 * * *$ & $18 \pm 2$ & 0.966 \\
\hline \multirow[t]{2}{*}{${ }^{241} \mathrm{Am}$} & I. oros & - & - & - & - & - & - & - & - \\
\hline & A. cavernicola & $\mathrm{T}$ & $79 \pm 8$ & $0.470 * * *$ & $1.5 \pm 0.3$ & $19 \pm 18$ & 0.047 & $15 \pm 8$ & 0.969 \\
\hline
\end{tabular}

$\mathrm{O}$ and T: 1- and 2-component exponential models, respectively; $\mathrm{A}_{0 \mathrm{~s}}$ and $\mathrm{A}_{01}$ : assimilation efficiency of the short- and long-lived component, respectively; SE: standard error; kes and kel : depuration rate of the short- and long-lived component, respectively; $\mathrm{T}_{\mathrm{b}^{1 / 2 \mathrm{~s}}}$ and $\mathrm{T}_{\mathrm{b}^{1 / 2} / \mathrm{l}}$ biological half-life of the short- and long-lived component, respectively; $\mathrm{R}^{2}$ : determination coefficient; p-values: $<0.001(* * *),<0.01(* *),<0.05(*),>0.5(\mathrm{~ns})$. 
Figures

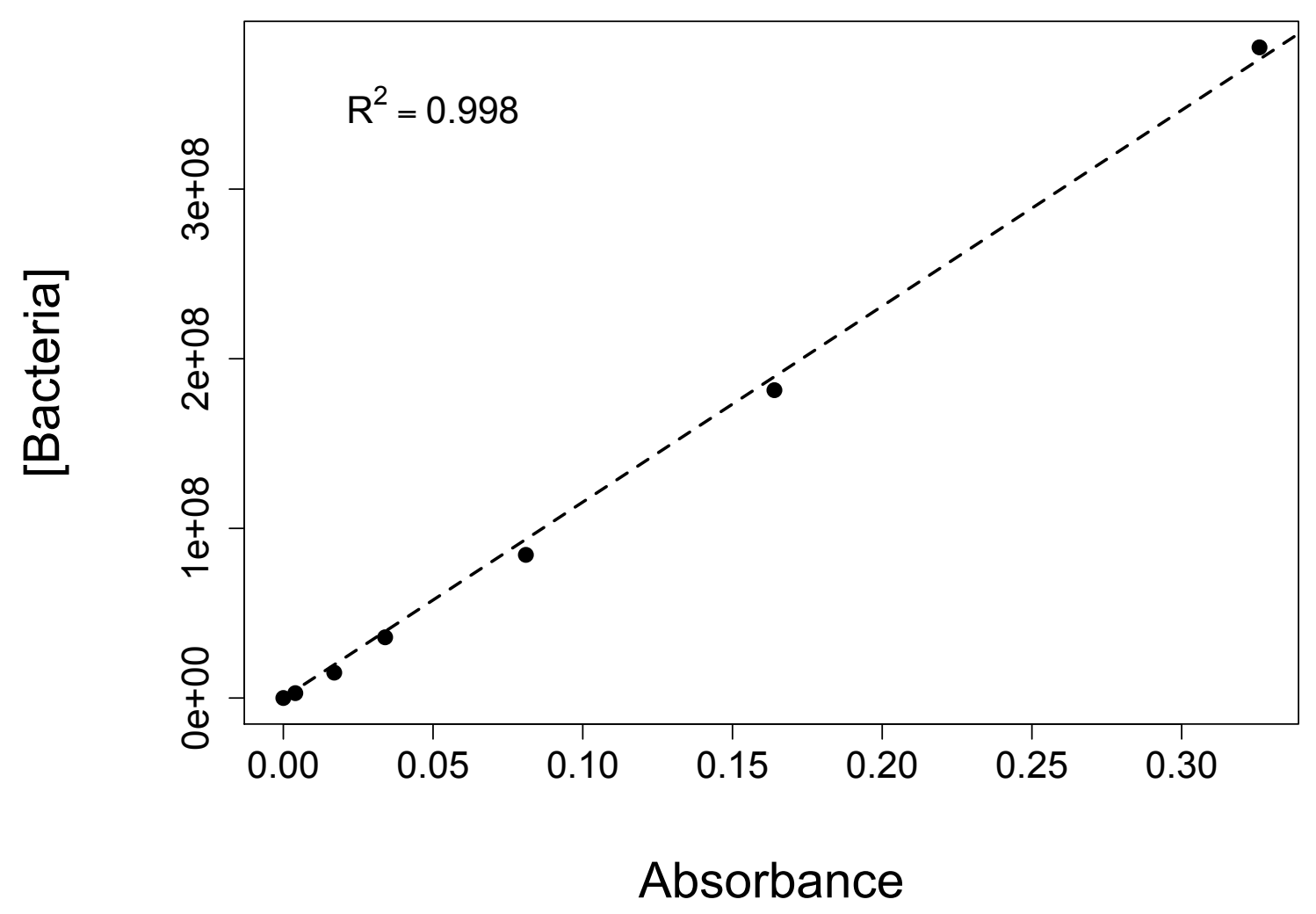

Figure 1. 


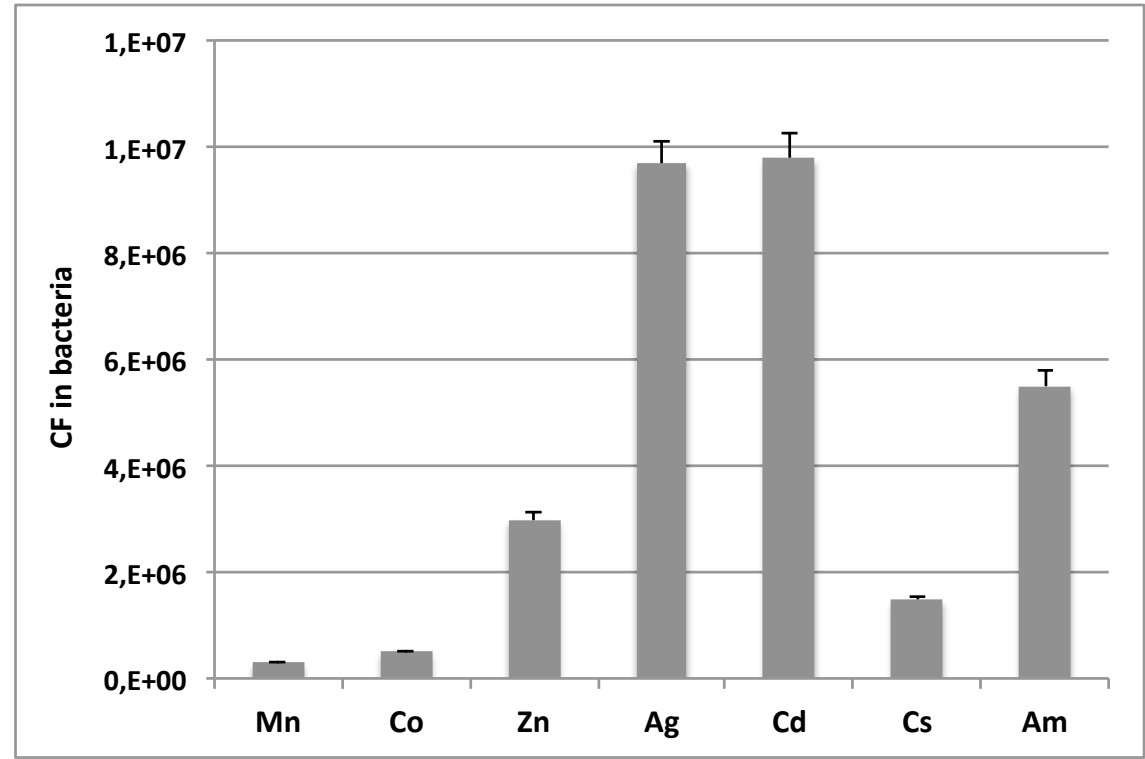

Figure 2. 

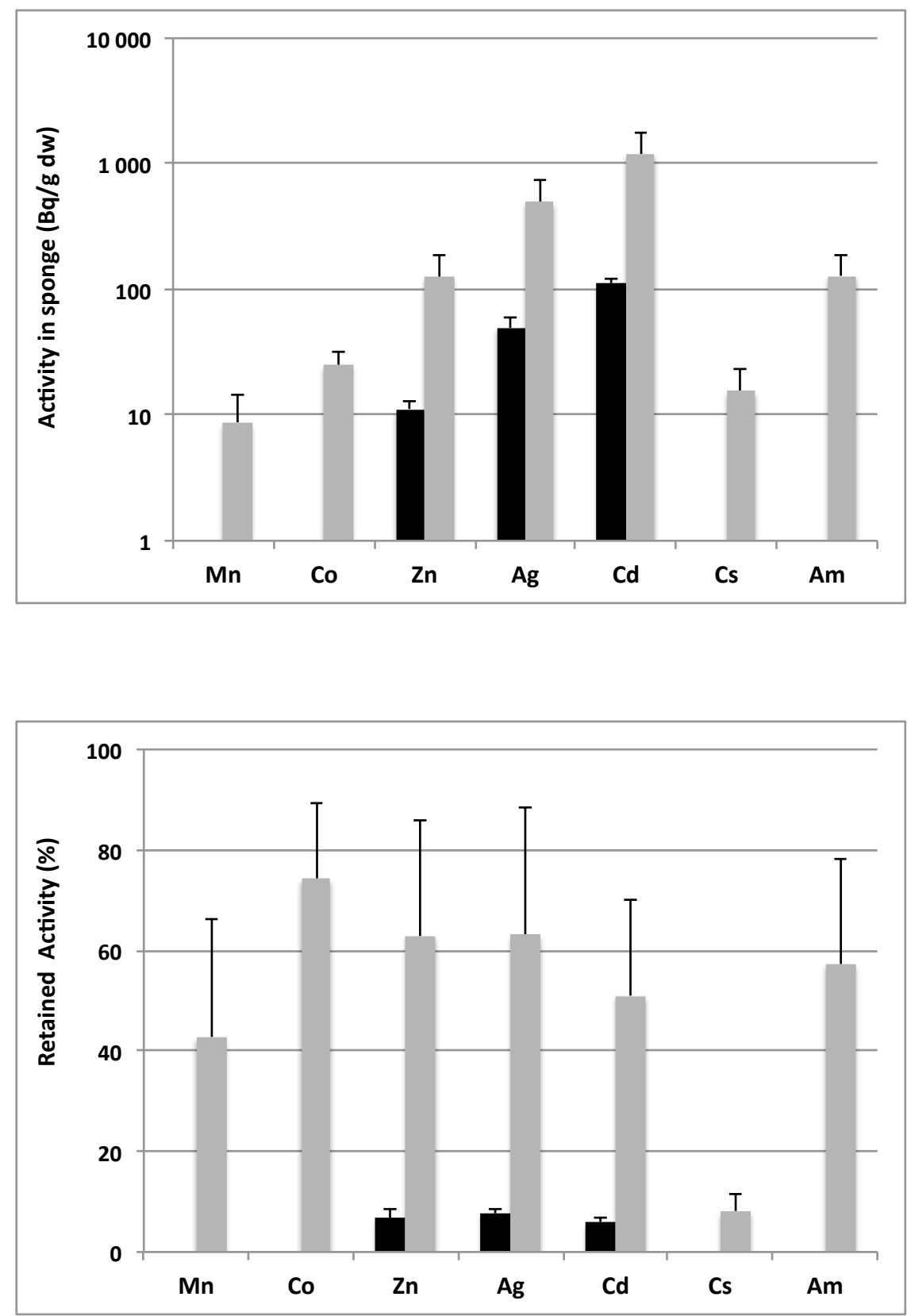

Figure 3. 


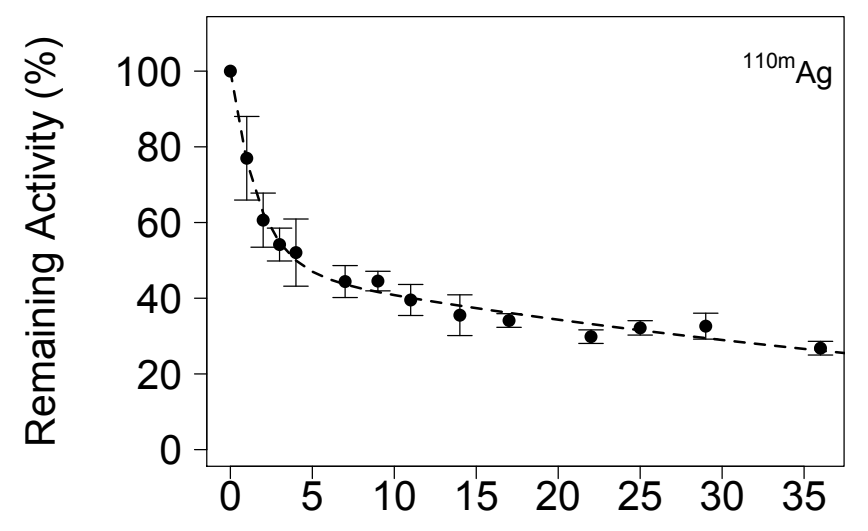

time (d)

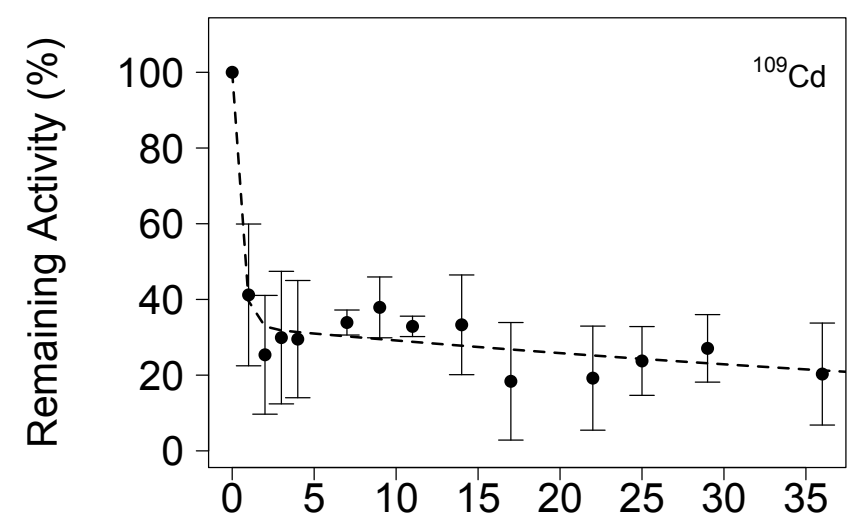

time (d)

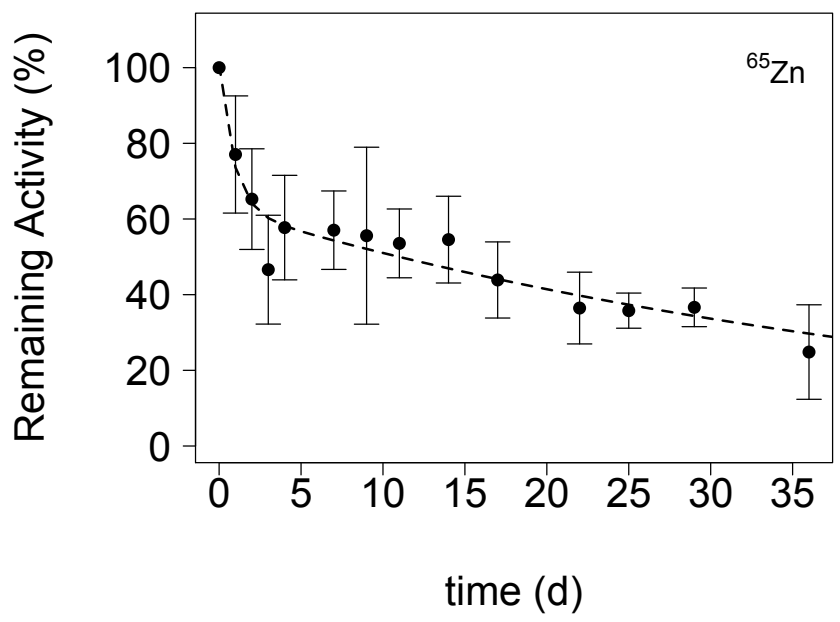

Figure 4. 

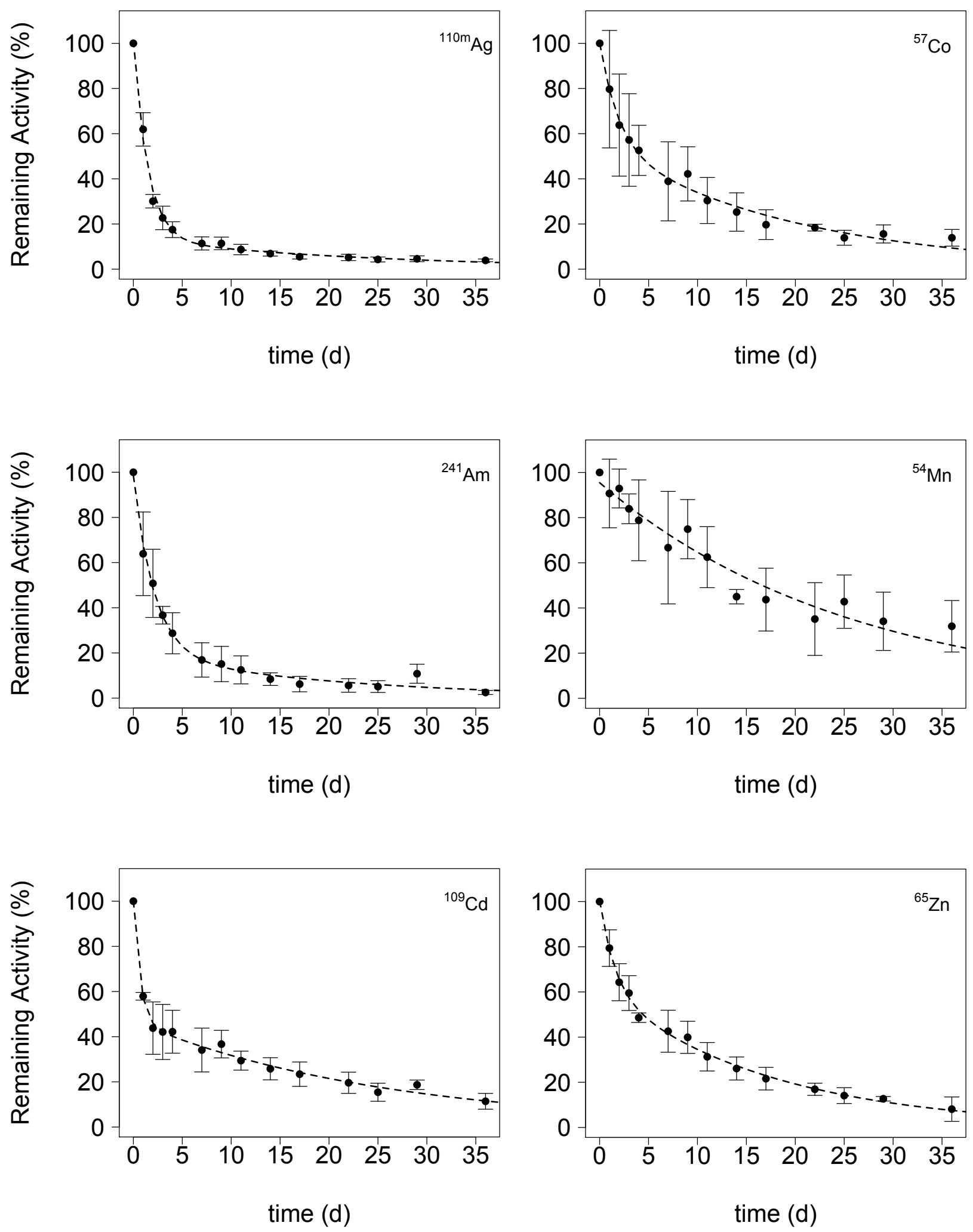

Figure 5. 